\title{
REKONSTRUKSI DIMENSI TRANSENDENTAL DAN SOSIAL GENERASI "Z" MASYARAKAT GUNUNG KEMUKUS SRAGEN PASCA PENUTUPAN LOKALISASI
}

\author{
Muhammad Miftah \\ Institut Agama Islam Negeri (IAIN) Kudus, Jawa Tengah \\ mubammadmiftab@stainkudus.ac.id
}

\begin{abstract}
Mindset is formed from the pattern of interaction among the individualswhose habit and daily behavior, then it is always repeatedso it becomes a character. The leverage level of generation $Z$ mindset is still very vulnerable because they are influenced by environment and technological developments. They are literate and always interact with technology in life activities. The environmental urge and patterns of interaction within a community in various researches play the most vital role in human behavior change. This theory is used as the foundation of the writer to conduct research in the area of Mount Kemukus which has become a place of ritual "lokalisasi" that impersonate religion for many years. This condition gets big attention from local governments and world. However, the stigma began to erode through government policy toclose those places and save Mount Kemukus from immoral practices. This research will focus on examining how the local government's education policy reconstructs the generation $Z$ mindset without excluding the ancestral culture (local wisdom) as the regional distinction compared to other regions. The government policy in reconstructing the millennial
\end{abstract}


mindset can be seen from policies in social, educational, economic and religious dimensions.

Keywords: Mindset, Generation Z, Education Policy Local Wisdom.

\begin{abstract}
Abstrak
Mindset terbentuk dari pola interaksi antara individu satu dengan individu yang lain yang memproyeksikan kebiasaan dan perilaku keseharian yang selalu dilakukan secara berulang-ulang bingga menjadi tabiat yang mengakar kuat dalam jiwa manusia. Tingkat labilitas mindset generasi $Z$ masih sangat rentan sekali dipengarubi oleh lingkungan dan perkembangan teknologi yang ada di sekitarnya, mengingat generasi $Z$ merupakan generasi yang melek dan selalu berinteraksi dengan teknologi dalam aktivitas kehidupannya. Urgenitas lingkungan dan pola interaksi dalam sebuah komunitas dalam pelbagai riset memegang peranan yang paling vital dalam perubahan perilaku manusia. Teori inilah yang dijadikan pijakan penulis untuk melakukan riset di kawasan Gunung Kemukus yang sudah menjadi maklum bersama sebagai tempat ritual "lokalisasi" yang berkedok agama selama bertahun-tahun hal inilah yang menjadi perhatian pemerintah daerah maupun dunia internasional. Namun, stigma itu mulai terkikis melalui kebijakan pemerintah dalam menutup lokalisasi Gunung Kemukus dari praktik-praktik asusila. Fokus riset ini akan membidik bagaimana kebijakan pendidikan pemerintah setempat dalam merekonstruksi mindset generasi $Z$ tanpa menyampingkan budaya lelubur (baca: local wisdom) sebagai distingsi daerah ini dibandingkan dengan daerah yang lainnya. Kebijakan pemerintah dalam merekonstruksi mindset generasi milineal yang ada disana bisa dilihat dari kebijakan dalam dimensi sosial, pendidikan, ekonomi, dan keagamaan.
\end{abstract}

Kata Kunci:Mindset, Generasi Z, Education Policy, Local Wisdom.

\title{
A. Pendahuluan
}

Gunung Kemukus menjadi bagian dari destinasi wisata unggulan kota Sragen selain memiliki pesona alam dan nuansa religi yang kuat, serta mitos "pesugihan" yang selalu bersanding dan mengiringi perkembangan objek wisata ini, yang berada di 
Dusun Gunung Sari Desa Pendem, Kecamatan Sumberlawang Kabupaten Sragen. Tidak hanya wisatawan lokal, maupun nasional yang datang untuk sekedar melihat fenomena yang berkembang di daerah Gunung Kemukus, banyak juga peneliti nasional maupun internasional yang mencoba mengungkap dimensi-dimensi yang mengitari objek wisata Gunung Kemukus dari berbagai aspek.

Objek wisata Gunung Kemukus sempat menjadi viral karena penelitian yang dimuat dalam journal of Sexual Medicine, memberitakan adanya ritual sex yang di legalkan dikawasan gunung kemukus, kegiatan seks dilakukan setelah para peziarah melakukan ziarah ke makam Pangeran Samudro. Geliat para peziarah terlihat riuh ketika malam jumat pon, karena masyarakat umum berkeyakinan malam jumat pon adalah waktu yang tepat untuk melakukan ziarah. Perilaku menyimpang yang dilakukan para peziarah pasca ziarah ialah melakukan hubungan badan dengan lawan jenis yang tidak sah (baca: tidak suami istri). Rosy Edwards dalam risetnya yang diberi judul "Sex Around the World: An Indonesian Festival of Sex With Stranger" mengungkapkan ritual seks dilakukan dengan alasan untuk mendapatkan keberuntungan dan harapannya dapat segera terealisasi.

Praktik menyimpang yang dilakukan para peziarah untuk melakukan hal yang bertentangan dengan norma agama ini, banyak dpengaruhi mitos yang berkembang dimasyaakat yang tidak bisa dipertanggung jawabkan akan kebenarannya. Motif peziarah dalam melakukan ritual seks banyak dipengaruhi informasi "sesat" yang berkembang dimasyarakat tentang bagaimana kisah cinta Pangeran Samoedro dan Nyai Ontrowulan, yang menjalin hubungan cinta terlarang di daerah Gunung Kemukus, sampai saat ini kisah ini menjadi kontroversi akan kebenarannya.

Jika kita menilik biografi Pangeran Samoedro, ia merupakan salah satu tokoh yang mempunyai kapasitas keilmuan agama yang mumpuni di masanya, hal ini menjadi maklum karena secara genetik Pangeran Samoedro merupakan cucu dari Sunan Hadi (kakeknya) dan Sunan Kalijogo (Eyang Buyut). Kepiawaiannya 
dalam berdakwah kala itu pernah mendirikan pesantren sederhana di daerah Gondang Jenalas (daerah sekitar $6 \mathrm{Km}$ dari Gunung Kemukus) disana Pangeran Samoedro menyebarkan agama Islam dan memiliki banyak pengikut. ${ }^{1}$ Salah satu bukti bahwa Pangeran Samoedra memiliki banyak pengikut ialah disekitar makam Pangeran Samoedra terdapat juga makam para pengikut setia Pangeran Samoedra yang dikebumikan disana.

Kontroversi tentang ritual seks yang ada di Gunung Kemukus yang viral membuat geram pemerintah kabupaten dan provinsi untuk mengambil kebijakan tentang penutupan lokalisasi Gunung Kemukus yang tertera dalam Surat Edaran (SE) Pemerintah Kabupaten (Pemkab) tentang larangan operasional hiburan karaoke yang diterbitkan pada tahun 2017. Namun secara realitas praktik prostitusi yang ada di daerah Gunung Kemukus sampai saat ini masih ada walaupun tidak semasif sebelum diterbitkannya SE, praktek seks menyimpang yang berada ditengah-tengah masyarakat umum inilah yang ikut mewarnai kultur dan pandangan pemuda yang kita sebut dengan Generasi Z yang mukim dan bermasyarakat di wilayah Gunung Kemukus.

Generasi Z merupakan generasi yang tidak bisa dilepaskan dari perkembangan tekhnologi informasi, secara teori generasi Z merupakan segmen sosial yang tumbuh dan lahir di era perkembangan digital yang begitu pesat.Kemudahan akses dan kemahiran generasi $Z$ dalam mendapatkan informasi dari gawai yang dimiliki memunculkan kekhawatiran tersendiri, terlebih generasi ini masih rentan dipengaruhi lingkungan sosial yang kurang positif. Daerah gunung kemukus yang populer sebagai tempat ritual seks berkedok religi menjadikan mindset generasi Z yang berada di gunung kemukus dan sekitarnya salah, mereka beranggapan ritual ziarah kubur yang di lanjutkan dengan praktek prostitusi merupakan kegiatan yang sah dan tidak bertentangan dengan norma sosial dan agama, praktik menyimpang ini secara

${ }^{1}$ S Djajadi, Jejak Pangeran Samoedro Gunung Kemukus (Surabaya: Lancar Agung, 2010), 47. 
tidak langsung membentuk pemahaman sosial keberagamaan para generasi Z masyarakat Gunung Kemukus.

Perubahan sosial, dapat dilihat dari segi struktural masyarakat seperti pola-pola perilaku dan pola interaksi antar anggota masyarakat. Perubahan pada segi kultural masyarakat seperti nilai-nilai, sikap-sikap, tatanan dari individual, keluarga dan masyarakat, perubahan yang dapat mengubah ketidakseimbangan (disequilibrium) dalam suatu sistem masyarakat. ${ }^{2}$ Dinamika perubahan kultur budaya yang muncul atas tabiat yang dianggap benar oleh mayoritas masyarakat, yang sejatinya tabiat yang ada bertentangan dengan norma agama dan susila sangat berbahaya bagi peradaban bangsa yang berkarakter ketimuran.

Pembentukan karakter seseorang sangatlah dipengaruhi dengan kondisi lingkungan yang mengelilinginya, lingkungan inilah yang akan membentuk bagaimana watak dan karakter seseorang, lingkungan yang baik akan menghasilkan karakter seseorang itu akan baik, jika lingkungannya buruk maka dapat dipastikan karakter yang muncul dari masyarakat tersebut ialah karakter yang kurang baik. Sedangkan Swastha menambahkan bahwa tradisi, kebiasaan, kebudayaan dan tingkat pendidikan ikut mempengaruhi pembentukan sikap. Proses menanamkan sikap anak terhadap sesuatu objek dapat melalui proses modeling yang semula dilakukan dengan secara mencontoh atau meniru prilaku seseorang yang menjadi idolanya, karena salah satu karakteristik anak yang sedang berkembang adalan keinginan untuk melakukan peniruan apa yang dilihat baik oleh dirinya.

Praktik sosial dalam kerangka pemikiran Bourdieu merupakan hasil dari pertautan beberapa konsep habitus, modal dan ranah.Dari beberapa praktik sosial keagamaan yang muncul tersebut pada dasarnya merupakan hasil dari pengintegrasian dari beberapa konsep tersebut. Habitus merupakan sebuah proses pemahaman terhadap skema benar dan salah yang ada dalam

${ }^{2}$ Idi Abdullah, Sosiologi Pendidikan, Individu, Masyarakat, Dan Pendidikan (Jakarta: Raja Grafindo, 2013), 208. 
ranah tertentu, ranah yang merupakan sebuah arena pertarungan akan menjadi lokus bagi terciptanya habitus. Sehingga dalam proses terbentuknya habitus akan terdapat modal yang bermain didalamnya, salah satunya merupakan modal budaya atau pengetahuan yang dimiliki oleh individu. Modal budaya inilah yang kadang dapat bertambah seiring berjalannya waktu, yang kemudian dapat menciptakan sebuah habitus baru karena muncul skema kebenaran baru yang diterima didalamnya. Inilah yang mendasari bahwa habitus itu bersifat fleksibel dan dapat berubah seperti yang dikatakan oleh Bourdieu, bahwa habitus adalah suatu sistem disposisi yang berlangsung lama dan berubah-ubah (durable, transposible disposition) yang berfungsi sebagai basis generatif bagi praktik-praktik yang terstruktur dan terpadu secara objektif. ${ }^{3}$

Memudarnya pemahaman sosial keagaman dikalangan pemuda sangatlah dipengaruhi dengan perkembangan tekhnologi, latar belakang pendidikan, dan sosial keberagamaan yang berkembang dimasyarakat.Para pemuda di lingkungan Gunung Kemukus sekarang ini lebih mementingkan peningkatan kepemilikan alat tekhnologi yang baru ketimbang, meningkatkan pengetahuan keagamaannya.Pemahaman keagamaan para pemuda juga dipengaruhi oleh ritual yang sudah lama mengakar di wilayah Gunung Kemukus.

\section{B. Pembahasan}

\section{Realitas Generasi Z}

Problematika yang selalu mengglayuti generasi $\mathrm{Z}$ terkhusus pemuda yang berada di daerah gunung kemukus ialah penyimpangan sosial yang dilakukan secara masif dikalangan masyarakat yang dianggap sebagai kelumrahan dan menjadi suatu hal yang biasa.Maka inilah yang menjadi persoalan besar dalam riset ini, pemuda dan dinamika pergaulan dikalangan penyedia

${ }^{3}$ Richard Harker, ( Habitus $\times$ Modal $)+$ Ranab = Praktik (Yogyakarta: Jalasutra, n.d.), 13. 
jasa prostitusi yang secara tidak langsung memberikan pengaruh negatif pada pandangan sosial keberagamaan mereka.

Perubahan sosial bisa berupa kemajuan (progres) atau sebaliknya dapat berupa kemunduran (regres). Perubahan sosial tidak hanya membawa pengaruh positif bagi kehidupan masyarakat, tetapi juga berdampak negatif.Seorang pemangku kebijakan harus responsive dan antisipatif dalam memahami dinamika perubahan sosial ini yang berkembang dimasyarakat. ${ }^{4}$ Respon pemangku kebijakan dalam menangkap gejala yang ada dalam realitas dilapangan disesuaikan dengan kapasitas dan kemampuan ketika merancang sebuah kebijakan.

Dalam perencanaan pembangunan, data kependudukan memegang peran yang penting. Makin lengkap dan akurat data kependudukan yang tersedia makin mudah dan tepat rencana pembangunan itu dibuat. ${ }^{5}$ Masyarakat Gunung Kemukus dilihat dari data monografi terdiri dari lima RT (Rukun Tetangga) yang masing-masing RT terdiri dari dari kurang lebih 35 sampai 40 kepala keluarga, total jumlah kepala keluarga Gunung Kemukus ialah 218 kepala keluarga. Sedangkan jumlah karang tarunanya ada 3 organisasi pemuda masih aktif dalam kegiatan sosial dan kepemudaan, masing-masing anggota rata-rata berjumla 50-60 anggota. Usia anggota karang taruna yang ada di Gunung Kemukus relatif sangat muda banyak usia pelajar antara usia 15 sampai 25 tahunan, yang secara teori generasi masuk katagori generasi $\mathrm{Z}$.

Berdasarkan teori generasi yang dikemukakan para sosiolog, mendefinisikan rentang umur Generasi Z, dilihat dari tahun kelahiran 1995 hingga 2014 jika menggunakan teori ini maka usia generasi $Z$ paling muda saat ini ialah 4 tahun sedangkan usia generasi $Z$ paling tua ialah 23 tahun. Dari teori ini dapat dipetakan jumlah generasi $Z$ yang ada di Gunung Kemukus berdasarkan data yang ada, jumlah generasi $Z$ yang ada ialah 30\% dari populasi

\footnotetext{
${ }^{4}$ Abdullah, Sosiologi Pendidikan, Individu, Masyarakat, Dan Pendidikan, 207.

${ }^{5}$ Ida Bagoes Mantra, Demografi Umum (Yogyakarta: Pustaka Pelajar, 2015). 45.
} 
masyarakat Gunung Kemukus. Angka yang cukup fantastis dalam teori perkembangan penduduk secara makro.

Perkembangan jumlah penduduk dunia sangat erat kaitannya dengan perkembangan peradaban manusia dalam berinteraksi dengan alam sekitarnya, setidaknya ada tiga tahapan perkembangan peradaban manusia, Pertama, zaman dimana mulai dipergunakannya alat-alat untuk menanggulangi kehidupannya. Dalam sejarah kita mengenal dengan istilah Homo Sapiens dengan kera, kemudian kita kenal lagi dengan istilah zaman batu (Batu Tua, Batu Muda, Perunggu). Kedua zaman dimulainya usaha pertanian dengan menetap, zaman ini mengubah kehidupan dari masa perburuan menjadi masa kehidupan pertanian, dari masa nomad kemasa pemukiman. Ketiga zaman industrialisasi, zaman ini ditandai dengan tumbuh dan berkembangnya pusat-pusat industri dan semakin berkembangnya pusat pemukiman manusia. ${ }^{6}$

Posisi generasi Z terdapat pada zaman industrialisasi, dimana generasi $Z$ hidup dan bersosial ditengah perkembangan industri dan tehnologi yang berkembang begitu pesat yang mempengaruhi dinamika sosial kemasyarakatan.Interaksi sosial generasi Z memberikan kontribusi yang besar terhadap jaringan sosial komunitas sebaya, interaksi individu dalam jaringan sosial, serta jaringan sosial dengan kelompok jaringan sosial lainnya. Selanjutnya perkembangan dinamika sosial yang diciptakan generasi Z dalam masyarakat membentuk pola dan tabiat yang menjadi kebiasaan masyarakat sebagai wujud budaya yang disepakati dalam komunitas atau masyarakat.

Walhasil bentuk perilaku normal dan abnormal, perilaku menyimpang dari norma yang berkembang dalam kehidupan bermasyarakat dipengaruhi oleh budaya, mitos, dan hukum. ${ }^{7}$ Budaya dan hukum memberikan legitimasi perilaku sosial yang berkembang dimasyarakat baik perilaku sosial positif maupun negatif, perilaku sosial disini menunjukan sisi ketergantungan individu satu dengan

\footnotetext{
${ }^{6} \mathrm{R}$ Thomlinson, Population Dynamic (New York: Random House, 1965).

${ }^{7}$ Anwar Sutoyo, Pemahaman Individu (Yogyakarta: Pustaka Pelajar, 2014).
} 
individu lain, atau individu dengan komunitas masyarakat lainnya dalam memenuhi kebutuhan hidupnya. Hal ini berarti perilaku sosial yang dibenarkan oleh norma agama, sosial, dan moral memberikan ruang yang luas bagi individu dan masyarakat untuk bertegur sapa serta berinteraksi sesuai dengan kapasitas dan kebutuhan yang diinginkan.

Perlaku sosial yang sudah membudaya dianggap sebagai keyakinan dan tindakan-tindakan manusia dalam masyarakat, termasuk aturan dan pedoman bagi perilaku mereka dalam situasi yang sudah ditentukan. Pengembangan manusia tergantung pada karakteristik lingkungan. Karakteristik lingkungan yang sudah dikembangkan oleh masyarakat masa lampau terhadap konstitusi lingkungan budaya dengan interaksi sosial seseorang. ${ }^{8}$ Sikap dan budaya yang dikembangkan oleh pelaku sosial di lingkungan menjadi karakter yang melekat dan menjadi distingsi dengan daerah lainnya, karakteristik ini harus dijaga sebagai identitas pribadi untuk menjadi modal dalam bersaing dengan daerah lainnya dalam aspek sosial dan ekonomi.

\section{Kultur Generasi Z Masyarakat Gunung Kemukus}

Gunung Kemukus secara geografis berada disebelah utara kurnag lebih $30 \mathrm{~km}$ dari kota Solo, berada di tengah-tengah perlintasan jalan Solo-Porwodadi membuat objek wisata unggulan kota Sragen Jawa tengah ini mudah diakses beberapa moda transportasi, baik pesawat terbang, kereta api maupun angkutan umum. Kemudahan akses tranportasi ini membuat keberadaan objek wisata Gunung Kemukus selalu rame dikunjungi para wisatawan lokal maupun internasional.Menjadi bagian dari suku jawa yang dikenal memiliki stereotipe halus dan sopan masyarakat Gunung Kemukus juga menjunjung tinggi akan adat istiadat yang berkembang dimasyarakat sebagai warisan leluhur yang harus dilestarikan.

\footnotetext{
${ }^{8}$ Sutoyo.
} 
Bangsa Indonesia dikenal dengan adat ketimurannya yang kental tata pergaulan yang dianut masyarakatnya sangat kental dengan adat dan norma, oleh karena itu pergaulan yang menjurus pada pergaulan bebas dalam hal ini free sex masih menjadi hal yang tabu dalam kehidupan di Indonesia. ${ }^{9}$ Generasi Z masyarakat Gunung Kemukus memiliki kepribadian yang ulet, pantang menyerah dan bekerja keras.Sikap ini dapat dilihat dari bagaimana para pemuda untuk memenuhi kebetuhan hidupnya dengan memanfaatkan keuntungan demografi yang dimilikinya. Kreatifitas para pemuda yang ada di Gunung Kemukus dalam menangkap keuntungan sebagai pusat wisata religi kota Sragen, menjadi salah satu sumber ekonomi yang bisa diambil manfaatnya oleh generasi $Z$ yang ada di Gunung Kemukus.

Persepsi generasi Z masyarakat Gunung Kemukus tentang ritual seks yang ada di daerahnya terbelah menjadi dua pandangan. Kelompok pertama menganggap ritual seks yang ada di Gunung Kemukus merupakan hal yang wajar, dan kelompok ini tidak mempermasalahkannya serta menangkap potensi ini dengan berbagai inovasi kreatif di bidang ekonomi dalam menyambut wisatawan yang datang, sebagai masukan bagi komunitas dan penghasilan individu. Kelompok yang kedua ialah komunitas pemuda yang kontra dengan keberadaan ritual seks yang sudah mengakar kuat di lingkungannya, kelompok ini tidak setuju dan menolak akan bisnis prostitusi yang ada, bentuk perlawanan kelompok ini dengan membuat program-program positif untuk komunitas dan para anak-anak yang ada disekitar Gunung Kemukus diantaranya; pembelajaran mengaji, pelatihan kerajinan tangan, kegiatan olah raga serta kegiatan sosial keagamaan lainnya.

Melihat realitas generasi $Z$ yang berkembang di Gunung Kemukus merupakan buah dampak sosial dan latar belakang pendidikan yang dimilikinya. Keadaan seperti ini perlu pendekatan

${ }^{9}$ Diana Hardiyanti, "Hipotesis Sapir-Whorf Dan Tata Pergaulan Generasi Muda,” Lensa: Kajian Kebahasaan, Kesusastraan, Dan Budaya 1, no. 1 (March 1, 2011), https://doaj.org. 
psikologis untuk melihat gejala demikian sebagai konsekuensi dari ciri-ciri generasi muda yang labil, berorientasi pada diri sendiri, tidak logis dalam membuat keputusan, pemberontak, emosional. ${ }^{10}$ Faktor latar belakang pendidikan dan lingkungan membentuk pola fikir dan pandangan para pemuda dalam melihat realitas prostitusi di daerahnya, pasalnya kelompok yang pro akan kegiatan prostitusi dilihat dari latar belakang pendidikannya ialah mereka yang beralatar belakang pendidikan non agamis. Sedangkan kelompok yang kontra mayoritas mereka ialah mempunyai latar belakang pesantren atau minimal mereka aktif dalam organisasi kemasyarakatan Islam.

Adagium dalam salah satu perspektif ilmu sosial menyatakan bahwa lingkungan sosial sangat mempengaruhi perilaku seseorang. ${ }^{11}$ Teori ini terbukti lingkungan pendidikan mempunyai andil kuat dalam membentuk paradigma berfikir dalam melihat realitas kehidupan. Mindset yang terbentuk dari lingkungan pendidikan akan mengakar kuat karena mindset ini berlandaskan pemikiran logis dari pengalaman belajar di lingkungan pendidikan. Karakter seperti ini akan lebih bertahan lama dalam gempuran perkembangan zaman dan modernitas.

Kelompok yang kontra dengan praktik prostitusi Gunung Kemukus peneliti menggunakan dengan istilah generasi M, komunitas ini merupakan entitas pemuda yang memegang tuguh keimanannnya dalam menjalankan aktifitas kehidupannya, tanpa menyampingkan modernitas dan aspek religiusitas. ${ }^{12}$ Dimensi religius dan modernitas bagi generasi $\mathrm{M}$ merupakan kelumrahan yang sulit untuk dihindari, dua dimensi ini berjalan beriringan dan menguatkan segala potensi sumber daya yang dimiliki daerah wisata Gunung Kemukus sebagai tujuan destinasi wisata religi utama di kota Sragen dan sekitarnya.

\footnotetext{
${ }^{10}$ James E Gardner, Memahami Gejolak Masa Remaja (Jakarta: Mitra Utama, 1996).

${ }^{11}$ Noveliyati Sabani, "Generasi Millenial Dan Absurditas Debat Kusir Virtual," Informasi 48, no. 1 (July 25, 2018): 95-108, https://doi.org/10.21831/ informasi.v48i1.18078.

${ }^{12}$ Shelina Janmohamed, Generation M: Young Muslims Changing The World (London: I.B. Touris, 2016), 44.
} 
Selain latar belakang pendidikan ada beberapa faktor lain yang mempengaruhi pemikiran serta psikologis seseorang, faktor lainnya yang ikut andil dalam mempengaruhi psikolgis sesorang ialah faktor fisiologis, proses fisiologis yang dialami manusia menjadi salah satu faktor yang dipercaya dapat mempengauhi factor psikologis adalah budaya yang dimiliki individu. ${ }^{13}$ Budaya yang di bangun dan dilestarikan atas dasar merawat nilai-nilai sosial dan agama yang dimiliki bangsa berperan dalam pembentukan watak masyarakat yang ikut andil dalam merawat kearifan lokal yang dimiliki bangsa.

Kebudayaan yang berfungsi sebagai roh objektif berisi unsur-unsur yang telah memperoleh pengakuan umum sebagai hal-hal yang bernilai, berharga, maka dari itu diberi kedudukan yang lebih tinggi diatas roh subjektif atau roh individual. Dengan demikian individu tidak dapat menghindari atau melepaskan diri dari pengaruh roh objektif, justru semua individu mendapat pengaruh dari susunan dan keadaan-keadaan lingkungan sosial tempat mereka hidup. ${ }^{14}$ Mereka sangat meyakini bahwa konten-konten itu adalah fakta sehingga berupaya untuk mempertahankannya dengan keras. Sosialisasi dan penerapan peraturan, literasi media sosial adalah beberapa cara yang bersifat eksternal yang dapat dilakukan untuk mengatasi persoalan tersebut. ${ }^{15}$

Sebagaimana telah disampaikan bahwa mereka yang lerlahir pada era generasi $Z$ merupakan anak yang sangat melek teknologi atau net generation. Mereka lebih menyenangi berinteraksi dengan komputer dan berkomunikasi dengan sistem online sehingga mereka punya kecenderungan untuk tidak bertemu dengan temantemannya. Sepertinya bagi anak generasi Z, ruang itu tidak dibatasi oleh halhal yang fisik, karena mereka bisa menciptakan ruang dalam status maya. Paham demikian ternyata mempunyai pengaruh besar dalam aktivitas bermain mereka. Bagi mereka bermain tidak mesti

${ }^{13}$ Sarlito W Sarwono, Psikologi Lintas Budaya (Jakarta: Raja Grafindo, 2015), 23.

${ }^{14} \mathrm{Ki}$ Fudyartanta, Psikologi Kepribadian Paradigma Filosofis, Tipologis, Psikodinamik Dan Organismik-Holistik (Yogyakarta: Pustaka Pelajar, 2012), 94.

${ }^{15}$ Sabani, "Generasi Millenial Dan Absurditas Debat Kusir Virtual." 
harus berada dalam ruang bermain fisik namun bisa digantikan dengan ruang maya. ${ }^{16}$

Bertransisi ke masa dewasa adalah salah satu tahap perkembangan manusia dimana selama itu remaja harus beranjak dari dependensi ke independensi, dan mengembangkan otonomi dan kematangan, konsekuensinya mereka di hadapakan pada banyak tantangan. ${ }^{17}$ Sebagai mahluk sosial, manusia terikat dalam satu sistem sosial dengan segala komponennya, seperti pranata sosial, tatanan hidup bermasyarakat yang disangga oleh nilainilai, baik nilai agama, moral, budaya adat dan lain lain. Budaya mempengaruhi cara kita menerima dan memproses informasi mengenai lingkungan disekitar kita. ${ }^{18}$

Ketika masa remaja tidak terperhatikan, bahkan pembinaan remaja di luar sekolah maupun di rumah diserahkan kepada masyarakat, yang ternyata kondisinya tidak kondusif bagi pengembangan karakter. Bahkan sampai masa dewasa, integrasi masyarakat tidak menentu, saling tidak mempercayai (trust), kehidupan semu, tidak tulus, Asal Bapak Senang, budaya munafik. Jadi ada sesuatu yang hilang (nothing to loose) yaitu karakter dan kearifan lokal. ${ }^{19}$ Maka akan muncul generasi Captive Audience (pendengar yang tidak punya plihan lain selain memperhatikan) inilah kondisi generasi $Z$ yang ada di masyarakat Gunung Kemukus karena tidak mempunyai power untuk sekedar membenarkan ataupun sekedar untuk menunjukan rasa tidak nyamannya kepada orang lain mereka tidak mampu, karena tertekan oleh kedaan lingkungan dan masyarakat yang ada.

${ }^{16}$ John Fredy Bobby Saragih, "Fenomena Bermain Generasi Z Dan Hubungannya Dengan Eksistensi Ruang Bermain Terbuka Di Lingkungan Perumahan Sederhana," ComTech: Computer, Mathematics and Engineering Applications 3, no. 1 (June 1, 2012): 8-14.

${ }_{17}$ Kalthtyn Geldard, Konseling Remaja Intervensi Praktis Bagi Remaja Berisiko (Yogyakarta: Pustaka Pelajar, 2012), 62. 2004), 34

${ }^{18}$ Matsumoto Juang, Culture and Psychologi (Wadsworth Cengange Learning,

${ }^{19}$ Satrijo Budiwibowo, "Membangun Pendidikan Karakter Generasi Muda Melalui Budaya Kearifan Lokal Di Era Global," Premiere Educandum : Jurnal Pendidikan Dasar dan Pembelajaran 3, no. 01 (November 14, 2016): 41, https://doi. org/10.25273/pe.v3i01.57. 
Solusi yang dapat ditawarkan bagi generasi ini yaitu memberikan pendekatan moral melalui pendekatan klarifikasi nilai (Values Clarification). Dalam klarifikasi nilai disini generasi muda diberikan pemahaman tantang nilai-nilai yang berkembang di lingkungan. Klarifikasi nilai disini memberikan penegasan tentang nilai dan budaya yang berkembang di masyarakat, baik dan buruknya nilai nilai yang ada.

Nilai-nilai yang muncul didaerah Gunung Kemukus harus ada penegasan dari pemangku kebijakan akan asas kepatutan dan kesopanan yang berlandaskan dogma agama maupun sosial yang berlaku secara umum. Klarifikasi ini memberikan pemahaman bagi generasi $\mathrm{Z}$ dalam mengambil sikap atas realitas yang berkembang dimasyarakat. Sikap inilah yang muncul secara kolektif akanmembentuk habitus dan pada akhirnya akan menjadi budaya yang disepakati masyarakat dan lingkungan.

\section{Local Wisdom Based Education Policy}

Globalisasi dapat didefinisikan sebagai kesalingterkaitan segala aspek entah kebudayaan, perekonomian, perdagangan, tehnologi, entah yang lain melintasi batas-batas Negara. Implikasinya dalam kondisi praksis, globalisasi tidak hanya memberikan angin segar tentang kemajuan tehnologi dan perekonomian, tetapi menjadi bayang-bayang yang sangat menakutkan bagi formasi sosial-budaya lokal. Globalisasi di curigai akan memberangus nilainilai kearifan lokal yang menjadi identitas masyarakat. ${ }^{20}$ Sistem Pendidikan Nasional di Indonesia memberikan amanat besar bagi pemangku kebijakan untuk mengembangkan manusia Indonesia seutuhnya, dengan mengupayakan generasi penerus bangsa yang beriman dan bertakwa kepada Tuhan Yang Maha Esa dan budi pekerti luhur. ${ }^{21}$

${ }^{20}$ Muhammad Takdir Ilahi, Revitalisasi Pendidikan Berbasis Moral (Yogyakarta: Ar-Ruzz Media, 2012), 35.

${ }^{21}$ Fathiyah Hasan Sulaiman, Sistem Pendidikan Menurut Al-Ghazali, Solusi Menghadapi Tantangan Zaman. Terj Z.S. Nainggolan\& Hadri Hasan (Jakarta: Dea Pers, 2000), 17. 
Pendidikan akan selalu bergerak dinamis mengikuti pelbagai perkembangan yang ada, baik perkembangan ilmu pengetahuan, teknologi maupun informasi. Untuk itulah pendidikan menuntut perubahan dan pembaruan agar tidak tertinggal terhadap perkembangan yang ada. ${ }^{22}$ Inovasi pendidikan dapat dilakukan melalui regulasi yang di rancang dan disesuaikan dengan kebutuhan dan tantangan zaman, inovasi bukan berarti merubah total keadaan yang ada akan tetapi mengahadirkan warna baru dalam menghadirkan wujud pendidikan dalam berbagai unsurunsur komponen pendidikan.

Inovasi pendidikan melalui jalur regulasi kebijakan pendidikan dirasakan paling efektif dalam merubah citra pendidikan serta menjawab tantangan zaman yang berkembang. Masyarakat Gunung Kemukus yang memiliki karakter yang khas dibandingkan dengan masyarakat yang lainya, setidaknya mempunyai modal tersendiri dalam mengembangkan potensi Sumber Daya Manusianya melalui jalur pendidikan. Tahapan-tahapan inovasi yang dilakukan dalam mendesain kebijakan pendidikan yang perlu diperhatikan yaitu; pemerataan dan peningkatan kualitas pendidikan, memperluas layanan pendidikan, menyelaraskan peningkatan pembangunan dan pendidikan, meningkatakn efektifitas dan sistem penyajian pendidikan, dan melancarkan sistem informasi kebijakan.

Terwujudnya pendidikan yang menjunjung tinggi nilainilai kearifan lokal, perlu kontribusi dan peran serta, kerja sama masyarakat dan lingkungan tanpa menyampingkan potensi individu dengan segal dimensinya, baik ruhaniah, emosional, sosial, intelektual dan fisik. ${ }^{23}$ Peran serta masyarakat diperlukan sebagai penilai dan konsumen dari produk pendidikan yang diharapakan dari sebuah proses pendidikan, yang endingnya karakter model pendidikan seperti ini ialah model pendididkan yang menerima

${ }^{22}$ M Hasbullah, Kebijakan Pendidikan Dalam Perspektif Teori, Aplikasi Dan Kondisi Objektif Pendidikan Di Indonesia (Jakarta: Raja Grafindo, 2015). 1993), 61.

${ }^{23}$ Hasan Langgulung, Manusia Dan Pendidikan (Jakarta: al-Husna Dzikra, 
aspirasi masyarakat dan peka terhadapa lingkungan sekitar (baca: kearifan lokal) .

Pendekatan yang dilaksanakan menggunakan demi mewujudkan pendidikan yang berbasis kearifan lokal ialah dengan experiential learning, sebuah proses saat warga masyarakat belajar melalui berbagai kegiatan bersama yang sesuai dengan konteks kehidupan yang mereka jalani. ${ }^{24}$ Keberadaan objek wisata Gunung Kemukus diakui atau tidak memberikan dampak positif dari segi ekonomi warga Gunung Kemukus, dari sini pendidikan hadir untuk menangkap peluang yang dimiliki, dengan menghadirkan pendidikan yang mengembangkan wisata religi, pendidikan agama yang terintegrasi dengan pendidikan kebudayaan.

Proses pendidikan merupakan proses interaksi penuh individu satu dengan yang lainnya dalam hal ini masyarakat dalam merubah pola fikir yang berkembang di dalam masyarakat. Pola partisipatoris inilah yang menjamin akan keberhasilan suatu kebijakan, kebijakan yang tadinya hanya menggaung dalam suatu peraturan, dapat diimplementasikan dengan baik dilingkungan masyarakat. Oleh karena itu kebijakan yang ada seharusnya dapat memberikan ruang kepada masyarakat untuk kreatif dalam menjani kehidupan dan tidak pasrah akan budaya negatif yang berkembang di masyarakat. Semangat perubahan dan kebebesan dalam mendesain suatu kebijakan merupakan ruh dalam menciptakan kebijakan pendidikan tanpa menyampingkan aset loka yang ada dimasyarakat.

Upaya menjaga character building yang termaktub dalam empat pilar berbangsa dan bernegara salah satunya ialah melalui pendidikan. ${ }^{25} \mathrm{Pada}$ tahapan pengambilan kebijakan terlebih dahulu mempertimbangkan masak-masak (rasionalitas, proses, hasil, serta efek samping yang ada), semua jenis perumusan kebijakan selalu

${ }^{24}$ Nadhir Salahudin, Pendidikan Kewarganegaraan Berbasisis Masyarakat, Sadar Ekonomi Lokal Dan Aset Yang Tersedia (Surabaya - Indonesia: UIN Sunan Ampel, 2016).

${ }^{25}$ Kunawi dkk Basyir, Pancasila Dan Kewaganegaraan (Surabaya: Sunan Ampel Pres, 2013). 
berkaitan dengan aspek metapolicy karena menyangkut hakikat. Meta policy mempersoalkan latar belakang dan cara suatu kebijakan (termasuk pendidikan) dipikirkan dirumuskan, bahkan dilihat dari aspek filosofis kebijakan itu bisa muncul seperti apa. ${ }^{26}$

Jika kita melihat perjalanan historis pendidikan Islam dari pra dan pasca kemerdekaan memang tidak terlalu diperhatikan oleh pemerintah namun pendidikan Islam masih tetap dapat survive di pelbagai situai dan kondisi yang sangat sulit. Hal inilah yang menjadikan pendidikan Islam menyandang berbagai nilai luhur. ${ }^{27}$ Pertama; Nilai Historis, pendidikan Islam mampu survive mulai dari masa kolonial hingga masa kemerdekaan, dengan tetap menjunjung tinggi nilai-nilai luhur budaya dalam kesinambungan hidup bangsa. Kedua; Nilai Religius, selain menjaga budaya bangsa, pendidikan Islam dalam perjalanan sejarah ikut mewarnai budaya dan keanekaragaman bangsa. Ketiga; Nilai Moral, Pendidikan Islam tidak diragukan lagi sebagai pusat pemelihara dan pengembang moral anak bangsa, nilai-nilai akhlakul karimah yang selalu dijadikan pijakan dalam mendesain kebijakan pendidikan baik pendidikan nasional maupun kebijakan yang dikeluarkan Kementerian Agama.

Dalam perumusan sebuauh kebiijakan, tim perumus kebijakan setidaknya memiliki dua pendekatan dalam perumusan kebijakan. ${ }^{28}$ Pertama; Sosial Demand Approach adalah pendekatan dalam hal ini kebijakan pendidikan diseseuaikan dengan kebutuhan masyarakat serta kebutuhan masyarakat., dalam domain ini pemangku kebijakan harus turun gunung memantau aspirasi serta menangkap harapan dan keinginan dari lapisan bawah, pendekatan ini dirasakan efektif karena diseseuaikan dengan apa yang dibutuhkan oleh masyarakat yang nantinya secara langsung

${ }^{26}$ A Rusdiana, Kebijakan Pendidikan Dari Filosofi Ke Implementasi (Bandung: Pustaka Setia, 2015), 23. 2000), 78 .

${ }^{27}$ H.A.R Tilaar, Paradigma Baru Pendidikan Nasional (Jakarta: Rineka Cipta,

${ }^{28}$ Arif Rohman, Kebijakan Pendidikan: Ideologi, Proses Politik, Dan Peran Birokrasi Dalam Formulasi Dan Implementasi Kebijakan Pendidikan (Pustaka Pelajar, 2002), 13. 
merasakan produk pendidikan. Kedua; Man Power Approach pendekatan dalam hal ini yaitu harus memperhatikan pertimbangan rasional Sumber Daya Manusia yang dimiliki negara, kapasitas serta kapabilitas menjadi acuan yang tidak dikesampingkan dalam perumusan kebijakan pendidikan.

Teori besar inilah yang menjadi pijakan pemerintah Kabupaten Sragen dalam mendesain kebijakan dalam dunia pendidikan dilingkungan Sragen yang ternasuk didalamnya yaitu daerah Gunung Kemukus; Pertama Kebijakan Menjadikan Daerah Wisata Religi; keputusan pemerintah Sragen untuk menjadikan Objek Wisata Gunung Kemukus menjadi objek wisata religi unggulan disragen ditanggapi positif dari berbagai ormas dan elemen masyarakat diantaranya MUI (Majelis Ulama Indonesia) Sragen mengapresiasi dan mendukung sepenuhnya kebijakan ini. Tidak mau ketinggalan Organisasi Kemasyarakatan Nahdhatu Ulama ikut membantu dalam merekonstruksi stigma negatif yang muncul dikalangan masyarakat dengan mengadakan kegiatankegiatan keagaman didaerah Gunung Kemukus.

Kedua; Kebijakan Mengaji dan Belajar pukul 18-20 WIB No Gawai\&No TV kebijakan ini dikeluarkan untuk mempersiapkan generasi penerus di wiayah Gunung Kemukus agar memliki Sumber Daya Manusia yang mumpuni dibidangnya. Selain para generasi pelajar kebijakan ini juga ditujukan kepada orang tua untuk mengawal para anaknya untuk memanfaatkan waktu antara jam 18.00 WIB sampai jam 20.00 WIB. Serta waktu ini tidak boleh ada aktifitas keluarga yang menggunakan pengeras suara (karaoke) kebijakan ini agar digunakan untuk pengembangan proses belajar anak dan waktu untuk keluarga.

Ketiga; Kebijakan dalam kepemudaan olahraga dan lainnya, kegiatan dalam bidang olahraga yang diagendakan secara periodk baik mingguan, bulanan maupun tahunan yang diadakan secara rutin. Kebijakan ini menyasar kepada para kaum muda yang masih muda untuk menyalurkan hobinya kehal-hal yang positif, serta meminimalisir kegiatan pemuda yang radikalis dan negatif. 
Keempat, merangkul usia produktif untuk belajar agama yang diadakan Kemenag Sragen. Kegiatan belajar agama yang diselenggarakan oleh Kementerian Agama menyasar para pemudi yang ada di daerah Gunung Kemukus untuk belajar agama BTA (Baca Tulis Al-Quran), Fiqih dan pembelajaran agama lainnya. Kegiatan ini rutin dilaksanakan setiap hari selasa siang dimasjid al- Hidayah, pembina kegiatan ini diampu oleh pegawai Kementeria Agama Sragen.

Kebijakan-kenijakan ini di buat untuk mewujudkan sistem pranata sosial, sistem pranata sosial yang terwujud ialah sebuah sistem dan norma yang saling terkait, beserta orang dan peralatan yang diperlukan, diorganisir sekitar pemenuhan kebutuhan atau fungsi sosial atau funsi sosial yang penting. ${ }^{29}$ Pendidikan merupakan sebuah pranata sosial yang berusia sama tua dengan masyarakat. Kedua-duanya terbentuk secara bersamaan, karena sejak awal keberadaannya dan untuk keberlangsungan hidupnya masyarakat memerlukan pendidikan yang dalam kehidupan keseharian, secara universal, merupakan fungsi utama dan tanggung jawab keluarga. ${ }^{30}$ Diferensiasi structural proses pembentukan lembaga-lembaga dalam hal ini lembaga pendidikan yang dilatar belakangi oleh keterbatasan waktu dan kemampuan secara akademis masyarakat dalam mendidik anak-anaknya, maka pada saat munculnya diferensiasi sosial maka munculah proses pengajaran serta berkaitan dengan kependidikan.

Bentuk perubahan sosial (social change) yang dirasakan pasca penutupan lokalisasi Gunung Kemukus dapat dipetakan menjadi dua dimensi, Pertama; Progres, yaitu perubahan sosial yang membawa kearah kemajuan sehingga dapat menguntungkan lingkungan yang ada di Gunung Kemukus. Bentuk progress disini juga dapat dipetakan lagi menjadi dua tingkatan yaitu; planned progress (kemajuan yang dikehendaki), kemajuan yang dikehendaki

${ }^{29}$ Sudardja Adiwikarta, Sosiologi Pendidikan Anaisis Sosiologi Tentang Praksis Pendidikan (Banung: Remaja Rosda Karya, 2016), 70.

${ }^{30}$ Adiwikarta, 71. 
dalam hal ini penutupan lokalisasi diharapkan muncul stigma positif masyarakat umum tentang keberadaan wisata religi yang ada di Gunung Kemukus. Pandangan positif inilah yang diharapkan dari kebiajakan penutupan lokalisasi Gunung Kemukus, yang tadinya menjadi pusat prostitusi yang mashur di tingkat lokal maupun internasional.

Perubahan sosial yang tanpa direncanakan (unplanned progress) kebijakan penutupan lokalisasi berdampak positif bagi perkembangan moral keagamaan generasi $Z$ yang ada di Gunung Kemukus, kemajuan ini dapat dilihat dari bagaimana pola interaksi serta kultur budaya religius yang berkembang pasca penutupan lokalisasi.

Kedua; regress (perubahan sosial yang mengarah pada kemunduran) kebijakan penutupan lokalisasi secara ekonomi menutup kran pendapatan masyarakat menurun drastis, pendapatan masyarakat yang mengandalkan wisatawan yang datang kegunung kemukus semakin berkurang seiring berkurangnya wisatawan yang dapat.Dilihat dari data pengunjung pasca penutupan lokalisasi pengunjung yang datang ke Gunung Kemukus menurun sampai $70 \%$.

\section{Simpulan}

Pendidikan nonformal memainkan peran strategis, baik sebagai pengganti, pelengkap atau penambah dari pendidikan formal, maupun sebagai penghubung jembatan kemampuan lulusan pendidikan formal, pendidikan nonformal menjadi pemeran utama bagi pendidikan orang dewasa pasca menyelesaikan pendidikan formal.Inilah wujud kebijakan pendidikan yang di kemas dalam menjaga nilai-nilai kearifan lokal yang ada di Gunung Kemukus. Lembaga pendidikan non formal yang berkembang di kawasan Gunung Kemukus merupakan jawaban akan keringnya pendidikan agama di daerah yang dikenal sebagai wisata religi. 
Mindset generasi $\mathrm{Z}$ masyarkat gunung kemukus dilihat dari aspek pendidikannya, setelah menyelesaikan pendidikannya formalnya, mayoritas mereka merantau dan tidak mau lagi mengembangkan potensi yang dimilikinya. Keterbatasan pendidikan nonformal yang ada di daerah gunung kemukus merupakan salah satu alasan yang membuat mereka tidak bisa berkembang. Latar belakang penddikan dan kultur budaya yang berkembang di daerah Gunung Kemukus inilah yang membentuk mindset generasi $\mathrm{Z}$ masyarakat Gunung Kemukus.

Dimensi yang paling menentukan bagi pendidikan generasi muda ialah dimulai dari scope yang paling rendah yaitu pendidikan keluarga. Pendidikan keluarga disinilah yang menumbuh kembangkan nilai-nilai moral dan budi pekerti yang akan membentuk kultur dan budaya kolektif yang di mafhum bersama oleh masyarakat sebagai tatanan yang di jadikan role masyarakat Gunung Kemukus dalam menjalankan aktifitas kehidupannya. Terwujudnya pendidikan yang menjunjung tinggi nilai-nilai kearifan lokal, perlu kontribusi dan peran serta, kerja sama masyarakat dan lingkungan tanpa menyampingkan potensi individu dengan segal dimensinya, baik ruhaniah, emosional, sosial, intelektual dan fisik. Peran serta masyarakat diperlukan sebagai penilai dan konsumen dari produk pendidikan yang diharapakan dari sebuah proses pendidikan, yang endingnya karakter model pendidikan seperti ini ialah model pendididkan yang menerima aspirasi masyarakat dan peka terhadapa lingkungan sekitar kearifan lokal. 


\section{Daftar Pustaka}

Abdullah, Idi. Sosiologi Pendidikan, Individu, Masyarakat, Dan Pendidikan. Jakarta: Raja Grafindo, 2013.

Adiwikarta, Sudardja. Sosiologi Pendidikan Anaisis Sosiologi Tentang Praksis Pendidikan. Banung: Remaja Rosda Karya, 2016.

Basyir, Kunawi dkk. Pancasila Dan Kewaganegaraan. Surabaya: Sunan Ampel Pres, 2013.

Budiwibowo, Satrijo. "MEMBANGUN PENDIDIKAN KARAKTER GENERASI MUDA MELALUI BUDAYA KEARIFAN LOKAL DI ERA GLOBAL." Premiere Educandum: Jurnal Pendidikan Dasar dan Pembelajaran 3, no. 01 (November 14, 2016). https://doi.org/10.25273/ pe.v3i01.57.

Djajadi, S. Jejak Pangeran Samoedro Gunung Kemukus. Surabaya: Lancar Agung, 2010.

Fudyartanta, Ki. Psikologi Kepribadian Paradigma Filosofis, Tipologis, Psikodinamik Dan Organismik-Holistik. Yogyakarta: Pustaka Pelajar, 2012.

Gardner, James E. Memahami Gejolak Masa Remaja. Jakarta: Mitra Utama, 1996.

Geldard, Kalthtyn. Konseling Remaja Intervensi Praktis Bagi Remaja Berisiko. Yogyakarta: Pustaka Pelajar, 2012.

Hardiyanti, Diana. "HIPOTESIS SAPIR-WHORF DAN TATA PERGAULAN GENERASI MUDA." Lensa: Kajian Kebahasaan, Kesusastraan, Dan Budaya 1, no. 1 (March 1, 2011). https://doaj.org.

Harker, Richard. (Habitus $\times$ Modal) + Ranah = Praktik. Yogyakarta: Jalasutra, n.d.

Hasan Sulaiman, Fathiyah. Sistem Pendidikan Menurut AlGhazali, Solusi Menghadapi Tantangan Zaman. Terj Z.S. Nainggolan\&Hadri Hasan. Jakarta: Dea Pers, 2000. 
Hasbullah, M. Kebijakan Pendidikan Dalam Perspektif Teori, Aplikasi Dan Kondisi Objektif Pendidikan Di Indonesia. Jakarta: Raja Grafindo, 2015.

Ilahi, Muhammad Takdir. Revitalisasi Pendidikan Berbasis Moral. Yogyakarta: Ar-Ruzz Media, 2012.

Janmohamed, Shelina. Generation M: Young Muslims Changing The World. London: I.B. Touris, 2016.

Juang, Matsumoto. Culture and Psychologi. Wadsworth Cengange Learning, 2004.

Langgulung, Hasan. Manusia Dan Pendidikan. Jakarta: al-Husna Dzikra, 1993.

Mantra, Ida Bagoes. Demografi Umum. Yogyakarta: Pustaka Pelajar, 2015.

Rohman, Arif. Kebijakan Pendidikan: Ideologi, Proses Politik, Dan Peran Birokrasi Dalam Formulasi Dan Implementasi Kebijakan Pendidikan. Pustaka Pelajar, 2002.

Rusdiana, A. Kebijakan Pendidikan Dari Filosofi Ke Implementasi. Bandung: Pustaka Setia, 2015.

Sabani, Noveliyati. "GENERASI MILLENIAL DAN ABSURDITAS DEBAT KUSIR VIRTUAL.” INFORMASI 48, no. 1 (July 25, 2018): 95-108. https:// doi.org/10.21831/informasi.v48i1.18078.

Salahudin, Nadhir. Pendidikan Kewarganegaraan Berbasisis Masyarakat, Sadar Ekonomi Lokal Dan Aset Yang Tersedia. Surabaya Indonesia: UIN Sunan Ampel, 2016.

Saragih, John Fredy Bobby. "Fenomena Bermain Generasi Z Dan Hubungannya Dengan Eksistensi Ruang Bermain Terbuka Di Lingkungan Perumahan Sederhana." ComTech: Computer, Mathematics and Engineering Applications 3, no. 1 (June 1, 2012): 8-14.

Sarwono, Sarlito W. Psikologi Lintas Budaya. Jakarta: Raja Grafindo, 2015. 
Sutoyo, Anwar. Pemahaman Individu. Yogyakarta: Pustaka Pelajar, 2014.

Thomlinson, R. Population Dynamic. New York: Random House, 1965.

Tilaar, H.A.R. Paradigma Baru Pendidikan Nasional. Jakarta: Rineka Cipta, 2000. 